\title{
On the nature of the Teisseyre-Tornquist Zone
}

\author{
Stanisław Mazur ${ }^{1}$, Piotr Krzywiec ${ }^{1}$, Michał Malinowski ${ }^{2}$, Marek Lewandowski ${ }^{2}$, \\ Paweł Aleksandrowski, ${ }^{3,4}$, Mateusz Mikołajczak ${ }^{1}$ \\ ${ }^{1}$ Instytut Nauk Geologicznych PAN; ul. Twarda 51/55, 00-818 Warszawa; \\ e-mail:ndmazur@cyf-kr.edu.pl,piotr.krzywiec@twarda.pan.pl,ndmikola@cyf-kr.edu.pl \\ ${ }^{2}$ Instytut Geofizyki PAN; ul. Księcia Janusza 64,01-452 Warszawa; e-mail: michalm@igf.edu.pl, lemar@igf.edu.pl \\ ${ }^{3}$ Państwowy Instytut Geologiczny - Państwowy Instytut Badawczy; ul. Rakowiecka 4, 00-975 Warszawa; \\ e-mail:pawel.aleksandrowski@pgi.gov.pl \\ ${ }^{4}$ Uniwersytet Wrocławski, Instytut Nauk Geologicznych; ul. Cybulskiego 30, 50-205 Wrocław
}

(C) 2018 Authors. This is an open access publication, which can be used, distributed and reproduced in any medium according to the Creative Commons CC-BY 4.0 License requiring that the original work has been properly cited.

Received: 10 January 2018; accepted: 9 February 2018

\begin{abstract}
The Teisseyre-Tornquist Zone (TTZ) is the longest European tectonic and geophysical lineament extending from the Baltic Sea in the NW to the Black Sea in the SE. This tectonic feature defines a transition zone between the thick crust of the East European Craton (EEC) and the thinner crust of the Palaeozoic Platform to the SW. The TTZ is evident from the seismic data as a perturbation of the Moho depth as well as from magnetic and gravity anomaly maps and heat flow distribution. For over a century, the TTZ has been considered a fossil plate boundary of the EEC corresponding to the limit of early Palaeozoic palaeocontinent Baltica. The results of quantitative interpretation of gravity and magnetic data, integrated with data from the new reflection seismic profiles crossing the TTZ, indicate the continuation of the Precambrian basement of the EEC and its lower Palaeozoic cover toward the SW underneath the Palaeozoic Platform. Potential field modelling also suggests the occurrence of a crustal keel underneath the TTZ. These results imply the location of a Caledonian tectonic suture, marking the site of the collision between Avalonia and Baltica, not along the TTZ, but farther SW, in NE Germany and SW Poland. Consequently, the extensive Permo-Mesozoic sedimentary basin of western Poland is established above the attenuated margin of the Baltica palaeocontinent.
\end{abstract}

Keywords: tectonics, Baltica margin, crustal architecture, potential field data, gravity and magnetic modelling, Caledonian suture, Poland

\section{INTRODUCTION}

The Teisseyre-Tornquist Zone (TTZ) is often recognised as the longest geological and geophysical lineament in Europe to the north of the Alps (Fig. 1; Pharaoh 1999). This transcontinental feature is well visible in seismic refraction data as a transition zone from the thick Precambrian crust of the East European Craton (EEC) to the thinner crust of the Palaeozoic Platform of Western Europe (e.g., Guterch et al. 2010). The TTZ is also unambiguously revealed by magnetic and gravimetric maps (e.g., Wybraniec 1999) as well as heat flow intensity (e.g., Čermák et al. 1989). Therefore, for decades, the TTZ has been considered a fossil plate boundary of the EEC and the dividing line between old Precambrian and younger Palaeozoic Europe (e.g., Tornquist 1908, Teisseyre 1921, Brochwicz-Lewiński et al. 1981, Pożaryski et al. 1982, Dadlez et al. 2005, Narkiewicz et al. 2015). There have also been minority views presented on a farther-reaching SW-ward extent of the EEC or only its lower crust to continue underneath the Palaeozoic Platform (Berthelsen 1998, Pharaoh 1999, Grad et al. 2002, Winchester et al. 2002, Malinowski et al. 2005, Żelaźniewicz et al. 2009). 


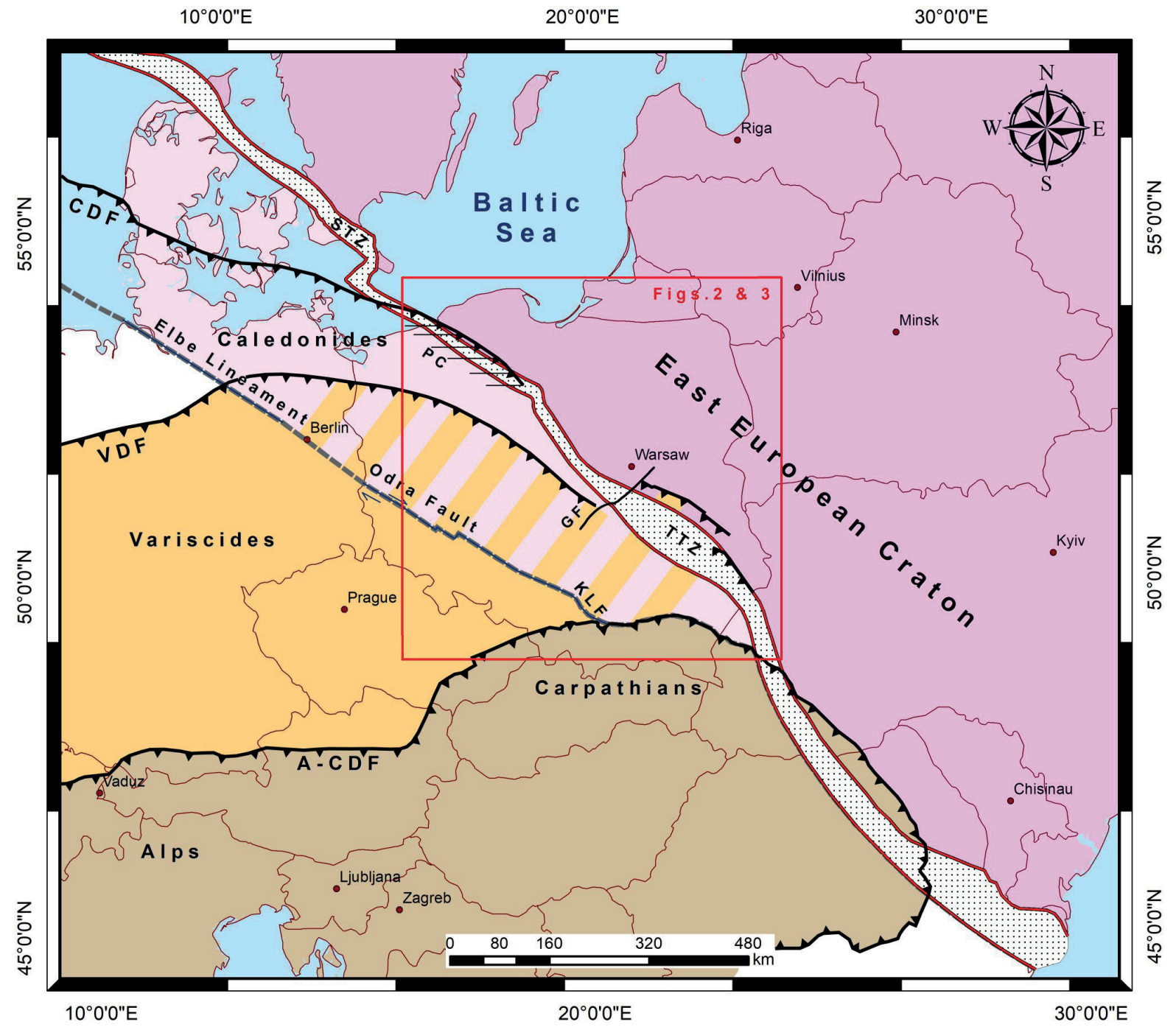

Fig. 1. Simplified tectonic map of Central Europe main structural elements and the position of the Teisseyre-Tornquist Zone. Base map modified from several sources including Franke et al. (1995), Pharaoh (1999) and Banka et al. (2002). Explanations: pink - East European Craton (EEC); pale pink - possible extension of the EEC beneath a thick sedimentary cover; orange - Variscides; beige - Alps and Carpathians; mixed orange and pale pink stripes - Baltica margin covered by the Variscan belt and its foreland basin; A-CDF - Alpine-Carpathian Deformation Front; CDF - Caledonian Deformation Front; GF - Grójec Fault; KLF - Kraków-Lubliniec Fault; STZ - Sorgenfrei-Tornquist Zone; TTZ - Teisseyre-Tornquist Zone; VDF - Variscan Deformation Front

The nature of the TTZ has remained unresolved for a long time due to the lack of adequate data on its in-depth architecture. This situation has changed with the emergence of the first high-resolution reflective seismic profiles imaging the structure of the SW slope of the EEC (Malinowski et al. 2013, Krzywiec et al. 2014). In this paper, following a similar account published in Polish language (Mazur et al. 2017), we present results of quantitative interpretation of gravimetric and magnetic data, integrated with interpretation of seismic reflection profiles from the PolandSPAN $^{\text {ma }}$ survey to explain whether the TTZ is a tectonic boundary of the EEC.

The new data indicate a continuation of the Precambrian crust of the EEC and its lower Palaeozoic sedimentary cover to the SW, beneath the Palaeozoic Platform of western Poland. They also suggest the presence of a crustal keel underneath the TTZ. In the wider context of European geology, these results imply the location of a Caledonian tectonic suture (Thor Suture), which defines the site of collision 
between Avalonia and Baltica, not along the TTZ, but farther to the SW, in NE Germany and SW Poland. Another implication is the location of extensive Palaeozoic and Permo-Mesozoic sedimentary basins of western Poland over the stretched and deeply concealed margin of the Baltica paleocontinent. The geophysical and geological arguments presented herein confirm the hypothesis (Mazur et al. 2016a, 2016b), according to which the TTZ was formed in the Precambrian and it was not the boundary of Baltica in the early Palaeozoic. They refer to the results of geophysical modelling using gravimetric and magnetic data and to the seismic interpretation of selected profiles of the PolandSPAN ${ }^{\mathrm{Tm}}$ survey (Krzywiec et al. 2014), which have been published in recent years (Mazur et al. 2015, 2016a, 2016b, 2017, Malinowski 2016, Krzywiec et al. 2017a).

\section{GEOPHYSICAL IMAGE OF THE TEISSEYRE-TORNQUIST ZONE}

The TTZ is about $50 \mathrm{~km}$ wide and is associated with a distinct change in the position of the Moho discontinuity. The Moho depth is reduced from 42-49 km underneath the Polish part of the EEC to $31-38 \mathrm{~km}$ in the area of the Palaeozoic Platform (e.g., Guterch \& Grad 2006, Guterch et al. 2010).
At the same time, the top of Precambrian basement is lowered within the TTZ by about $10 \mathrm{~km}$ towards the SW (Fig. 2; Mazur et al. 2015, Grad \& Polkowski 2016, Mikołajczak 2016, Krzywiec et al. 2017a). The shear wave (S) velocity distribution in the upper mantle obtained on the basis of seismic tomography proves that the TTZ coincides with a much wider transition zone between the high-velocity domain underneath the EEC and the low-velocity domain beneath the Palaeozoic Platform (Zhu et al. 2015). The TTZ also coincides with the direction of faster $S$ wave propagation in the upper mantle (Zhu \& Tromp 2013).

The TTZ is an essential boundary in the image of gravity and magnetic field (Królikowski \& Petecki 1995, Królikowski \& Wybraniec 1996, Wybraniec 1999), and also in the distribution of heat flow intensity (Čermák et al. 1989, Majorowicz et al. 2003). In general, the EEC, where the crystalline basement top is relatively shallow, corresponds to gravity and magnetic highs, while gravity and magnetic lows are characteristic of the Palaeozoic Platform, whose crystalline basement is placed at a considerable depth (Figs. 2, 3). Located between the two contrasting geophysical domains, the TTZ corresponds to a zone of maximum lateral gradient of gravity and magnetic field (Fig. 3).

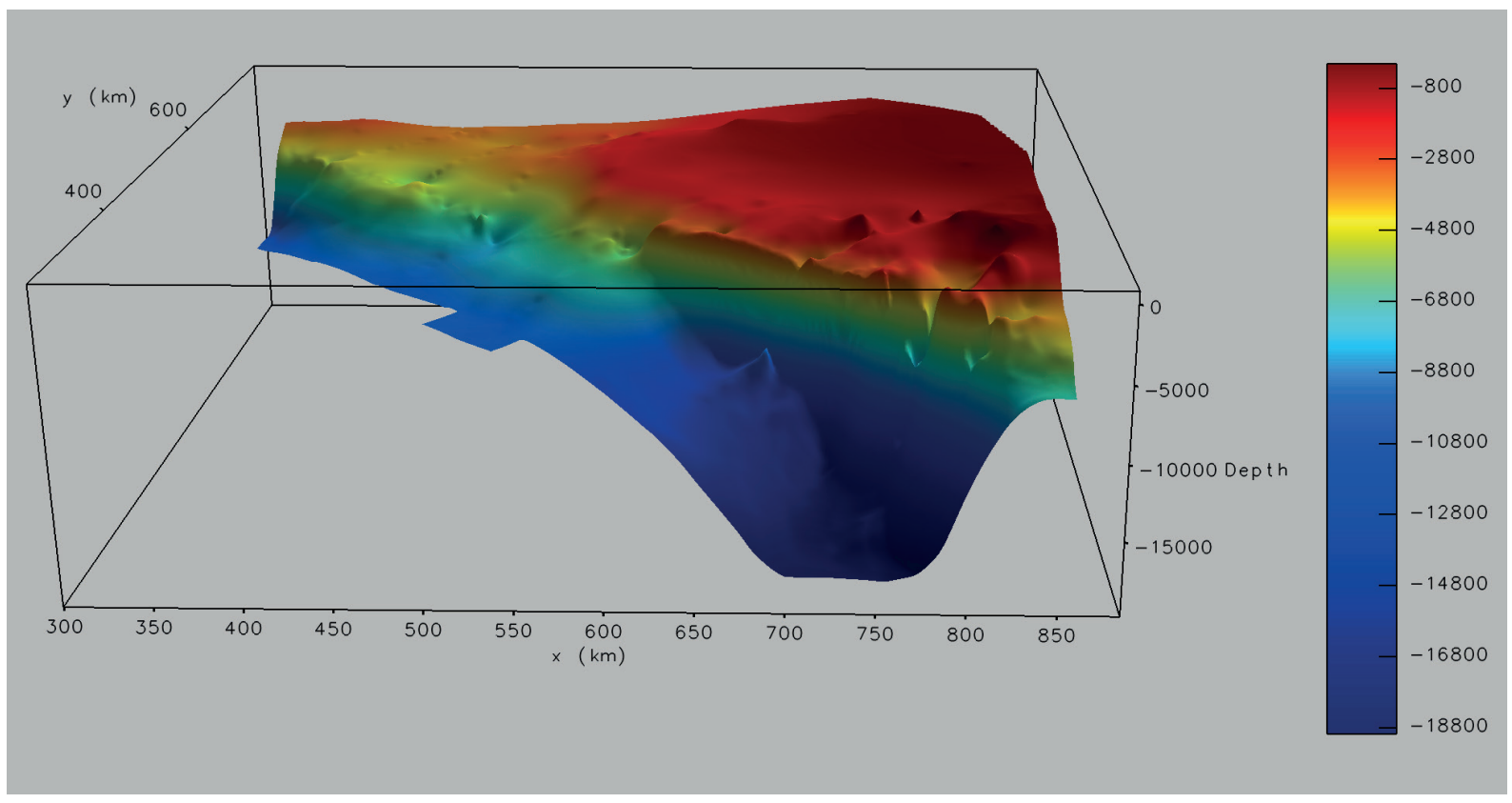

Fig. 2. Perspective view (looking northward) of crystalline basement configuration derived from 3D inversion of gravity data over the Teisseyre-Tornquist Zone and the Polish part of the East European Craton 
Throughout its length, the TTZ is covered by thick successions of Palaeozoic, Permo-Mesozoic and Cenozoic sedimentary basins. Therefore, the reconstruction of both the contemporary structure and the past tectonic evolution of the TTZ has to be primarily based on the interpretation of geophysical data in combination with the analysis of well data, whereas the surface geology does not play a role in this task.

\section{OBJECTIVES AND METHODS}

The starting point for the research presented herein was an observation that the TTZ in northern and central Poland is accompanied by large gravity lows (Pomeranian and Kuyavian Lows), extending parallel to the strike of this zone (Fig. 3A). At the same time, in SE Poland the TTZ crosses the area of the Małopolska Gravity High without substantially modifying it. While in the latter case positive gravity anomalies may be associated with the presence of high density bodies in the lower crust (e.g., Perchuć 1984, Malinowski et al. 2005, Janik et al. 2005, 2009, Środa et al. 2006), the presence of gravity lows in the TTZ has no simple explanation.

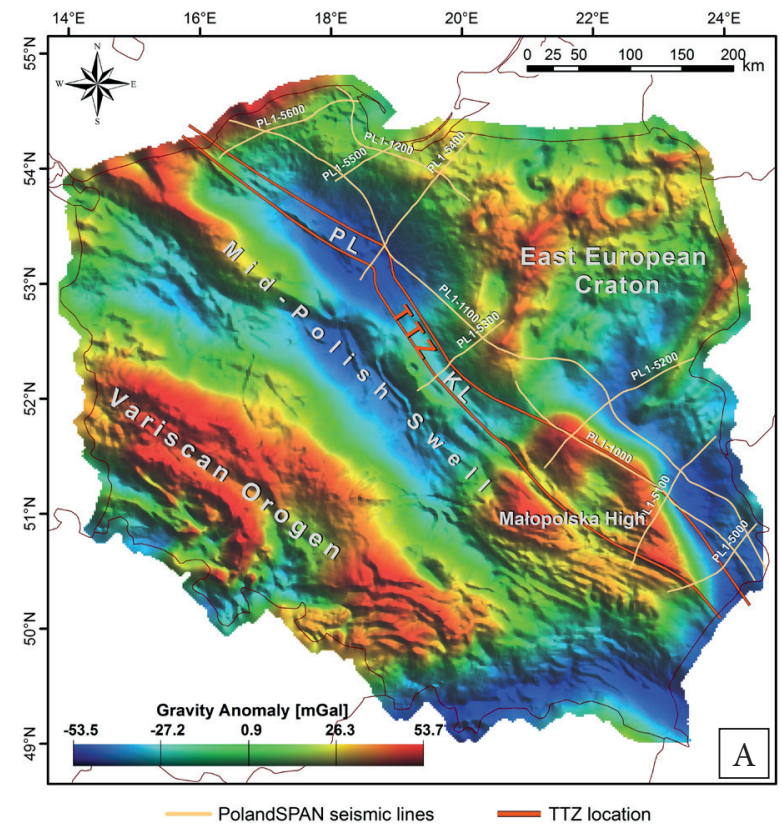

Considering the decrease of the Moho depth underneath the Palaeozoic Platform relative to the EEC (Grad et al. 2002, Guterch \& Grad 2006, Guterch et al. 2010), one would rather expect a gravity high along the TTZ. Of course, the effect of the SW-ward decrease in the depth to Moho is to some extent compensated by the descent of the top of crystalline basement in the same direction. To the extent that these two opposing tendencies balance one another, or an additional factor comes into play, the issue remains open. It cannot be resolved solely on the basis of qualitative observations without the aid of quantitative geophysical models. A similar situation occurs in the case of magnetic anomalies. It is not possible to assess, based on the qualitative analysis, whether a strong lateral magnetic field gradient in the TTZ (Fig. 3B) is merely the result of a deep burial of magnetic basement in the area of the Palaeozoic Platform or it ensues from the contact of crystalline basement blocks with different magnetic susceptibilities.

We used the results of seismic reflection profiles from the PolandSPAN ${ }^{\mathrm{m}}$ survey (Krzywiec et al. 2014) in the depth domain (Fig. 3) to create quantitative geophysical models for the TTZ.

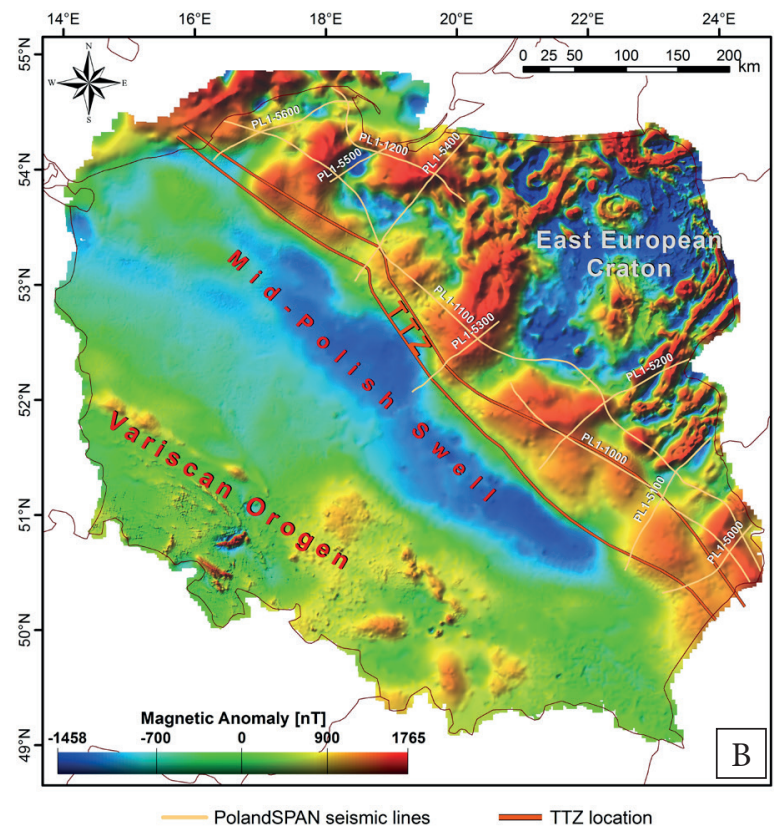

Fig. 3. Potential field anomaly maps for the territory of Poland. The coordinate system used is Poland 1992: A) Bouguer gravity anomaly map. The gravity data were derived from gravity ground stations and gridded at $2000 \mathrm{~m}$ interval. The Bouguer correction reduction density is $2.67 \mathrm{~g} / \mathrm{cm}^{3}$. B) Magnetic anomaly reduced to the pole (RTP). The total magnetic intensity grid was compiled from ground and airborne surveys and gridded at $500 \mathrm{~m}$ interval and upward continued to $500 \mathrm{~m}$ mean terrain clearance. Explanations: KL - Kuyavian Gravity Low, PL - Pomeranian Gravity Low, TTZ - Teisseyre-Tornquist Zone 
The use of seismic horizons for the sedimentary cover and top of crystalline basement has mostly solved the problem of non-uniqueness of geophysical models as it narrowed the range of possible solutions. Because PolandSPAN ${ }^{\mathrm{Tw}}$ profiles in their original version did not image the lower crust and Moho interface, we integrated them with gravimetric and magnetic data to obtain a full image of the TTZ. For modelling of the top of lower crust and Moho discontinuity, we used grids compiled by Majdański (2012) based on the results of all previous refraction experiments. However, horizons derived from seismic refraction data were treated more as a general guideline for modelling, allowing some derogation from seismic horizons if it was required to achieve a good fit between the observed and synthetic gravity and magnetic data.

The two-dimensional forward modelling of gravity and magnetic data was done along the PolandSPAN ${ }^{\mathrm{mm}}$ profiles, which intersect the whole or part of the TTZ (Fig. 3; Mazur et al. 2015, 2016a, 2016b, 2017, Mikołajczak 2016). Modelling was performed using the Geosoft GM-SYS software, which uses the classical Talwani \& Ewing (1960) method to calculate the gravity and magnetic responses of the bodies defined in the model. Density data were taken from the resources of the $\mathrm{Na}$ tional Geological Archive (Tab. 1), and for the deeper layers of the crust; their range was determined based on general knowledge about the petrophysical properties of rocks and the results of previously published models (Mazur et al. 2015 and references therein).

Three-dimensional modelling was based on the inversion of gravity data in the frequency domain (Barns \& Barraud 2012). The first step was to calculate the upper mantle gravity effect based on the assumption of a simple two-layer model. The Moho interface separating the two layers was based on a data grid derived from the combined results of seismic refraction sounding (Majdański 2012). The density contrast of $0.35 \mathrm{~g} / \mathrm{cm}^{3}$ across the Moho was assumed. The computed gravity signal from the upper mantle was then subtracted from the observed gravity data with the Bouguer correction. The gravity residual thus separated included anomalies generated by sources located in the Earth's crust. It was used in the inverse modelling to calculate the top of crystalline basement, assuming the density contrast of $0.2 \mathrm{~g} / \mathrm{cm}^{3}$ between the basement and sedimentary cover, as well as the lack of lateral density gradient.

\section{RESULTS}

The quantitative analysis confirmed several earlier observations concerning the TTZ (Królikowski \& Petecki 1995, Królikowski \& Wybraniec 1996, Wybraniec 1999). The results obtained show that the TTZ is located along the boundary between two contrasting domains, where the lateral gradients of gravity and magnetic field reach the maximum magnitude (Fig. 3). Two-dimensional modelling also confirmed the shallower depth to Moho underneath the Palaeozoic Platform (Fig. 4).

Besides similarities to the previously published data (Grad et al. 2002, Guterch \& Grad 2006, Guterch et al. 2010), the results also revealed features of the TTZ that have not yet been reported in the literature. First of all, it was found that balancing of the calculated gravity effect of models in the TTZ is not possible without a local depression of the Moho discontinuity. Three two-dimensional models (PL-5300, PL-5400 and PL-5600, Fig. 4) show the presence of a crustal keel underneath the TTZ in central and NW Poland (Fig. 4). The keel is $20-30 \mathrm{~km}$ wide and it is located below the axial part of the Kuyavian and Pomeranian Gravity Lows, penetrating the upper mantle to a depth of $46-48 \mathrm{~km}$, which is approximately $6-8 \mathrm{~km}$ below the Moho discontinuity in its immediate vicinity. For modelling, a minimum realistic density of the crust in the TTZ $\left(2.7 \mathrm{~g} / \mathrm{cm}^{3}\right)$ was assumed, which is smaller than that suggested by seismic refraction data (Grad et al. 2003, Guterch \& Grad 2006, Guterch et al. 2010). If density of the crust in the TTZ is increased accordingly to the seismic data, the crustal keel would be larger, probably as large as that illustrated in figure 8a in Grad et al. (2003). The keel would also have been larger if increased density of the upper mantle beneath the Palaeozoic Platform (see Grad et al. 2003, Janik et al. 2009), assumed for models PL-5300 and PL-5400, had been discarded. 

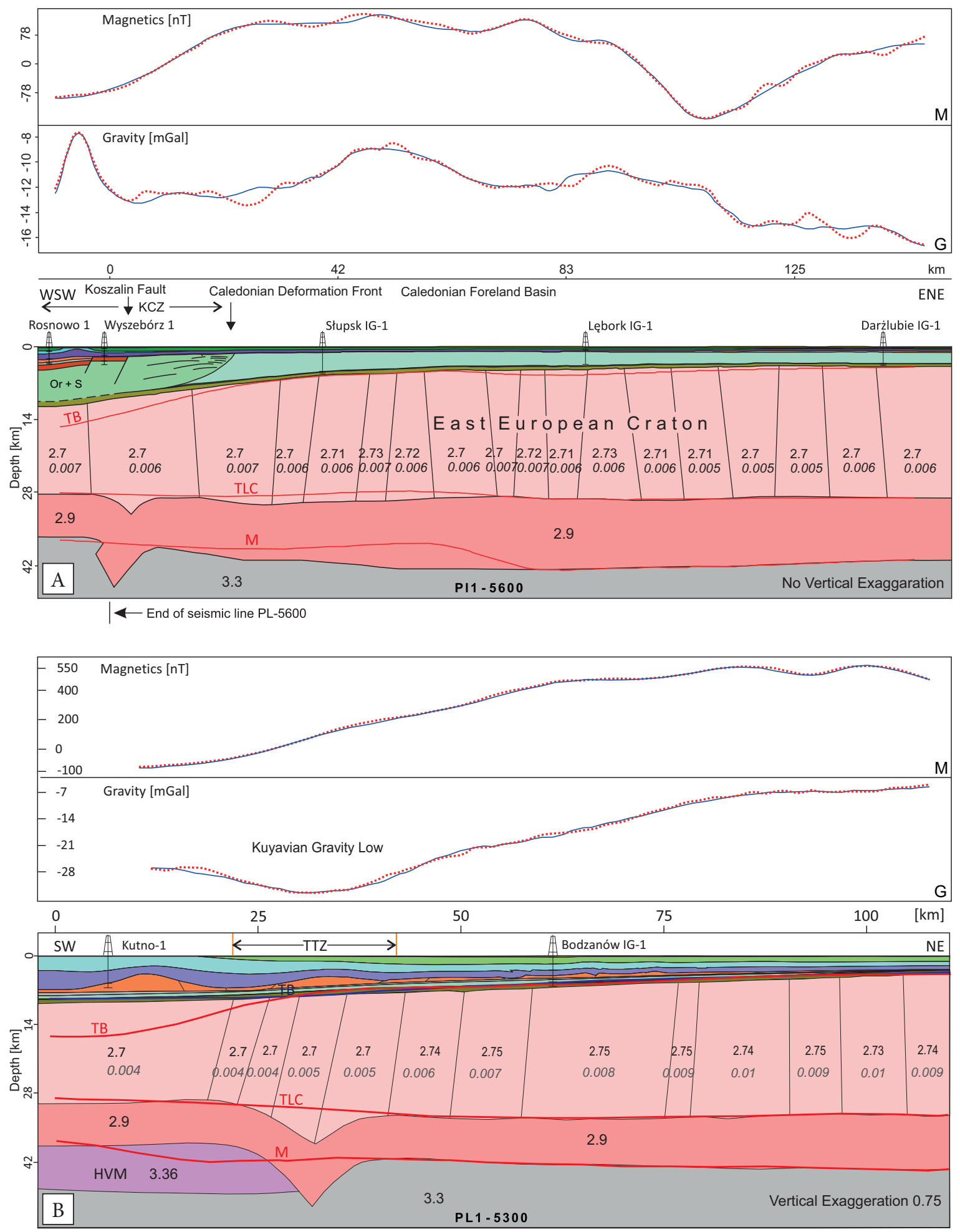

Fig. 4. Two-dimensional gravity, magnetic and geological models for selected PolandSPAN ${ }^{\mathrm{ma}}$ profiles. Explanations: $G-$ gravity profiles; M - magnetic profiles; thick red dotted line - observed data; thin blue solid line - synthetic response of the model; A)-D) geological models for profiles: PL1-5600 (A) after Mazur et al. (2016b) - the model is extended to the SW based on seismic refraction and well data; PL1-5300 (B) after Mazur et al. (2015); PL1-5400 (C) after Mazur et al. (2016a) - the model is extended to the SW based on seismic refraction data; PL1-5100 (D) - structure of the Phanerozoic portion of the section after Krzywiec et al. (2017a) and Moho after Malinowski (2016). Legend to colour coding and densities of Ediacaran and Phanerozoic layers 

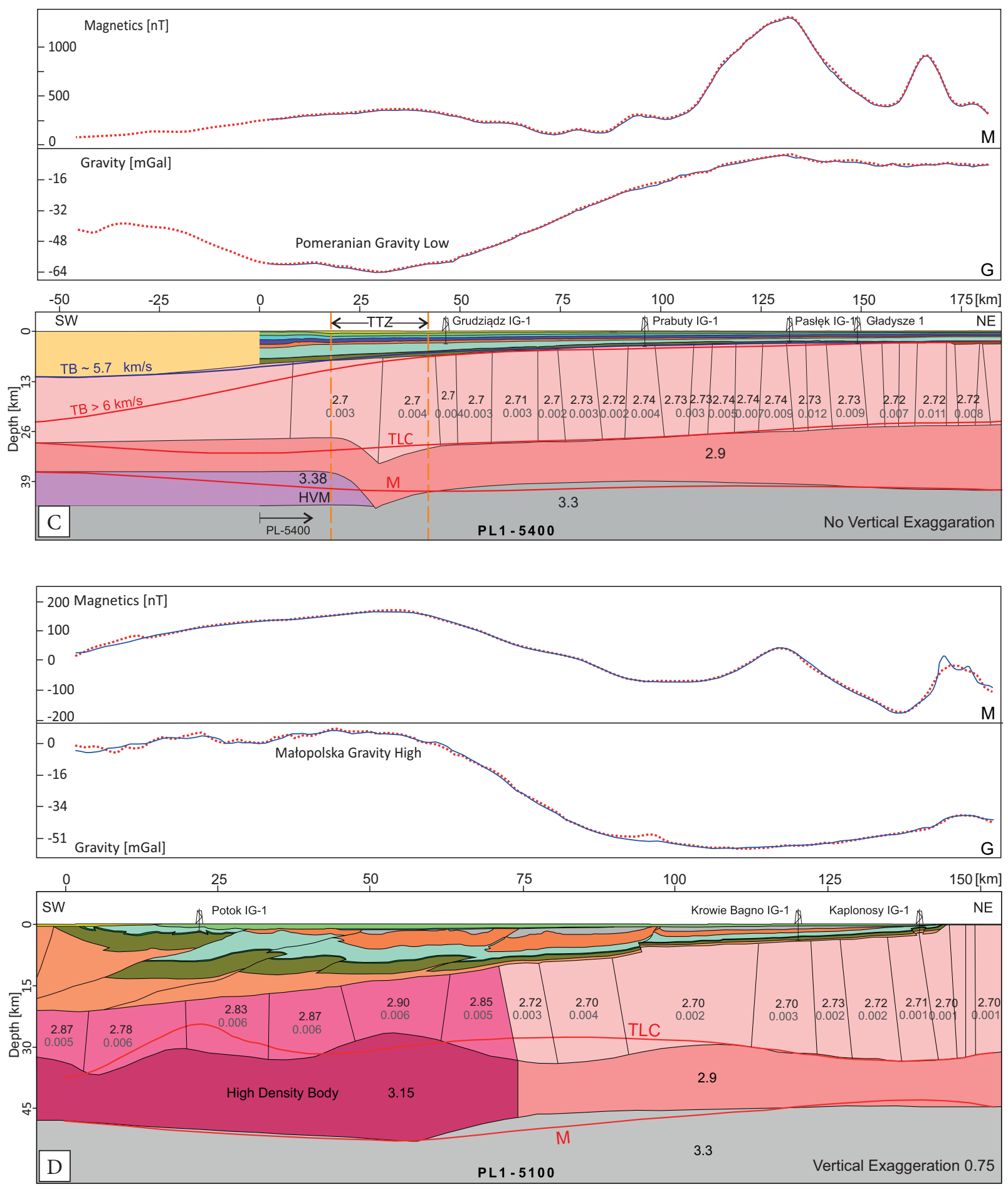

is provided in Table 1. Numerical values on models represent densities of the crystalline crust and upper mantle $\left[\mathrm{g} / \mathrm{cm}^{3}\right] ;$ those written in italics show magnetic susceptibilities in the crust [cgs]. Red horizons on geological models represent the position of Moho (M), top of lower crust (TLC) and top of crystalline basement (TB) based on interpolation of refraction data (Majdański 2012). Blue horizons on models B) and C) show the location of top of consolidated basement (TB) based on the 3D velocity model by Grad \& Polkowski (2016). HVM - high-velocity upper mantle; KCZ - Koszalin-Chojnice Zone; TTZ - Teisseyre-Tornquist Zone 
Table 1

Key to Phanerozoic stratigraphic subdivisions (including Ediacaran) used in geological models of Figure 4 and to density and susceptibility values used in modelling

\begin{tabular}{|l|c|c|c|}
\hline \multicolumn{1}{|c|}{ Layer } & Density $\left[\mathbf{g} / \mathbf{c m}^{3}\right]$ & Susceptibility $[\mathbf{c g s}]$ & Colour \\
\hline Cenozoic & $2.00-2.20$ & 0 & yellow \\
\hline Cretaceous & $1.94-2.39$ & 0 & green \\
\hline Jurassic & $2.10-2.44$ & 0 & blue \\
\hline Triassic & $2.30-2.70$ & 0 & violet \\
\hline Permian & $2.30-2.58$ & 0 & brown \\
\hline Carboniferous & $2.52-2.58$ & 0 & orange \\
\hline Devonian & $2.50-2.56$ & 0 & light blue \\
\hline Silurian & $2.56-2.68$ & 0 & dark green \\
\hline Ordovician & $2.65-2.70$ & 0 & faded green \\
\hline Ordovician and Silurian & 2.66 & 0 & olive green \\
\hline Cambrian & $2.60-2.70$ & $0-0.001$ & salmon \\
\hline Neoproterozoic & $2.67-2.70$ & & 0 \\
\hline
\end{tabular}

Both two- and three-dimensional models show the undisturbed top of the crystalline basement of the EEC, which plunges consistently towards the SW under the Permo-Mesozoic Polish Basin and the underlying Palaeozoic formations in the NW and the Łysogóry and Małopolska Blocks in the SE (Fig. 4). The top of the EEC basement is lowered in the TTZ to $11-13 \mathrm{~km}$ in NW and central Poland and to $16-18 \mathrm{~km}$ in SE Poland (Fig. 2). Magnetic profiles across the TTZ are characterized by a geometry roughly comparable to that of the top of basement, which descends to the SW (Fig. 4). This proves that the changing depth to crystalline basement is the main factor controlling the lateral magnetic field gradient in the TTZ. This conclusion is confirmed by the increase in the wavelength of magnetic anomalies above the EEC as it approaches the TTZ (Fig. 3B).

In summary, two-dimensional modelling showed no density contrast in the crystalline crust across the TTZ in central and NW Poland. Moreover, despite the use in the models of the minimum acceptable density for crystalline basement $\left(2.7 \mathrm{~g} / \mathrm{cm}^{3}\right)$, the negative gravity anomalies of Pomerania and Kuyavia were not reproducible without introducing a depression of the Moho discontinuity underneath the TTZ. In the Lublin region, the density contrast in the crust is high, but it is related to the presence of high density bodies within crystalline basement (Perchuć 1984, Malinowski et al.
2005, Janik et al. 2005, Środa et al. 2006). The top of the crystalline basement in two- and three-dimensional models is smooth, with no faults, and it does not reveal any signs of Phanerozoic deformation involving the crystalline crust of the EEC (Figs. 3, 4). This is additionally substantiated by the presence of tectonically undisturbed lower Palaeozoic sediments overlying the crystalline basement in the central part of the TTZ. The sedimentary succession is deformed in the NW and SE parts of the TTZ, but in both cases its deformation is thin-skinned, being associated with the Variscan folding and thrusting in the Lublin-Radom area (Antonowicz et al. 2003, Krzywiec et al. 2017a, 2017b) and Caledonian shortening in Pomerania (e.g., Mazur et al. 2016b). In the latter case, the folded Ordovician and Silurian sediments were thrust over the undeformed part of the Caledonian foreland basin, as indicated by the PL-5600 seismic profile (Fig. 4; Mazur et al. 2016b). This occurred during the final phase of the Caledonian orogeny when the foreland basin fill was partially incorporated into an orogenic wedge (Mazur et al. 2016b).

\section{DISCUSSION}

Over the last three decades, the TTZ has been mostly interpreted as a fossil terrane boundary formed in the Ediacaran-Early Palaeozoic along 
the SW margin of the Baltica paleocontinent (e.g., Franke 1995, Dadlez et al. 2005, Malinowski et al. 2015, Narkiewicz et al. 2015). Proponents of this hypothesis generally postulated a strikeslip nature of the tectonic suture along the TTZ (Brochwicz-Lewiński et al. 1984, Pożaryski 1990, Dadlez et al. 2005, Narkiewicz et al. 2015). However, the smooth, undisturbed geometry of the EEC top basement slope along the TTZ (Figs. 2, 4), revealed by the recent, high-resolution seismic reflection profiles of the PolandSPAN ${ }^{\mathrm{m}}$ survey (Mazur et al. 2015, 2016b, Krzywiec et al. 2017a) and deep reflection profile POLCRUST-01 (Malinowski et al. 2013, 2015, Krzywiec et al. 2017b), as well as by potential field modelling (Mazur et al. 2015, 2016a, 2016b, 2017), is difficult to reconcile with the presence of a Palaeozoic tectonic suture in this zone. This is also due to the presence of tectonically undisturbed lower Palaeozoic sediments covering the top of crystalline basement in central Poland (Fig. 4). Particularly, the latter observation suggests that the TTZ must have been created in the Precambrian. Consequently, if Baltica is defined as a paleocontinent resulting from the break-up of Rodinia in the Ediacaran (Torsvik et al. 1990, 1992) and existing until the collision with Laurentia in the Silurian, the crystalline basement blocks on both sides of the TTZ belong to Baltica. This also implies location of the Ediacaran rift axis farther west of the TTZ.

The extension of the Precambrian crust of the EEC in the substratum of the Palaeozoic Platform of central and western Poland has already been postulated by Berthelsen (1998), based on the LT-7 seismic profile. However, according to Berthelsen (1998), the TTZ was the Permo-Mesozoic "pseudo-suture" developed during the opening of the Polish Basin. It was considered to have formed over a low-angle, listric décollement in the ductile part of the crust due to the early Permian continental rifting, according to the classical Wernicke model (1985). The Berthelsen's model has been largely adopted in the review paper by Pharaoh (1999) that discussed the subsurface structure of the Trans-European Suture Zone (TESZ), corresponding to the SW margin of the EEC. At the same time, the Kraków-Lublinic Fault, delineating the present boundary between the Brunovistulian Terrane and Małopolska Block (Fig. 5), was interpreted as a potential limit of Baltica (Żaba 1999). However, other researchers, although inspired by Berthelsen's (1998) views, accepted them only partially. Grad et al. (2002) and Winchester et al. (2002) concluded that only the lower Baltica crust extends beyond the TTZ, reaching up to the Odra Fault (Fig. 5). The upper crust was, however, interpreted as an overthrust Caledonian accretionary prism. A view of the Avalonian provenance of the upper crust and its lower Palaeozoic cover underneath the Polish Basin was soon questioned on the grounds of learning that the Ordovician and Silurian sediments from the Koszalin-Chojnice Zone have Baltica-related sources (Nawrocki \& Poprawa 2006, Poprawa et al. 2006). At the same time, Dadlez et al. (2005), following in the footsteps of Brochwicz-Lewiński et al. (1984) and Pożaryski (1990), published a hypothesis explaining the TTZ as a Caledonian strike-slip suture, along which proximal terranes of Baltica provenance docked to the margin of Baltica proper. Although these authors did not refer to any new data, the undeniable advantage of their interpretation was prediction of the presence of the Baltica crust in the deep substratum of the Palaeozoic Platform to the SW from the TTZ. The interpretation by Dadlez et al. (2005) was also invoked in recently published papers based on the results of deep seismic reflection profile POLCRUST-01 (Malinowski et al. 2013, 2015, Narkiewicz et al. 2015), crossing SE Poland. Interestingly, it was done so even though the POLCRUST-01 profile unequivocally showed the SW-ward extension of the crystalline basement of the EEC with essentially undisturbed top, sloping below the Łysogóry and Małopolska Blocks, at a distance of at least $50 \mathrm{~km}$ beyond the TTZ (Malinowski et al. 2013, Krzywiec et al. 2017b).

Taking into account the tectonic context discussed above, the results presented herein seem to have a groundbreaking significance. Using the quantitative analysis of potential fields integrated with the PolandSPAN ${ }^{\text {su }}$ high-resolution seismic reflection data, the continuing and undisturbed top of the crystalline basement of the EEC, extending SW-ward beyond the TTZ was documented in central and northern Poland (Fig. 4), complementing the evidence supplied by the POLCRUST- 01 profile. 

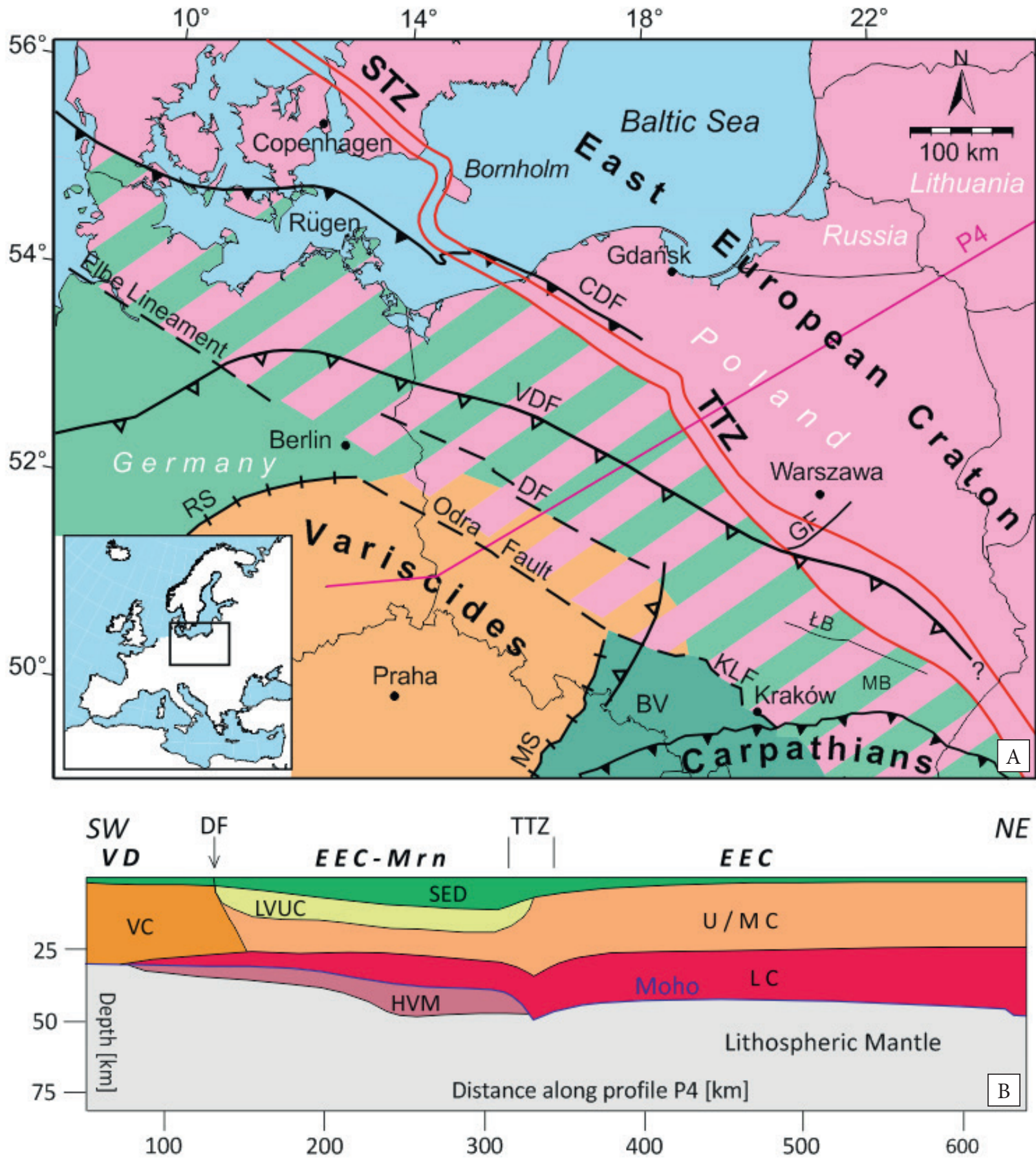

Fig. 5. Potential extent of the Precambrian crystalline socle of the Baltica margin in central and western Poland. Explanations: A) Extent of different crustal types of crystalline basement across the contact zone between the East European Craton and Palaeozoic Platform of Central Europe after Grad et al. (2002), modified. Purple line shows the location of P4 seismic deep refraction profile. Precambrian crust of the basement of the East European Craton is pink, Avalonian crust - green, Brunovistulian crust dark green and Variscan crust is orange in colour. Mixed green (or orange) and pink stripes mean crust of uncertain provenience that may represent the Baltica margin. BV - Brunovistulian Terrane; CDF - Caledonian deformation front; DF - Dolsk Fault; GF - Grójec Fault; KLF - Kraków-Lubliniec Fault; ŁB - Łysogóry Block; MM - Małopolska Block; MS - Moravian Suture; $R S$ - Rheic Suture; STZ - Sorgenfrei-Tornquist Zone; TTZ - Teisseyre-Tornquist Zone; and VDF - Variscan deformation front. B) Section across the SW margin of the East European Craton along seismic refraction line P4, based on a two-dimensional $P$ wave velocity model (Grad et al. 2003) and present results. DF - Dolsk Fault; EEC - East European Craton; EEC-Mrn - East European Craton margin; HVM - high-velocity mantle; LC - lower crust; LVUC - low-velocity upper crust; SED - sediments; TTZ - Teisseyre-Tornquist Zone; VC - Variscan/Gondwanan (?) crust; VD - Variscan Domain; U/MC - upper-middle crust 
Our results provide support for a substantial part of the Berthelsen's hypothesis (1998), according to which it is not only the lower crust, but the whole thickness of the crystalline crust of the EEC along with its lower Palaeozoic sedimentary cover that continues in the deep substratum of the Palaeozoic Platform in central and western Poland. A similar interpretation can be applied to the Małopolska and Łysogóry Blocks, whose deep crystalline basement, in the light of the data presented here and the earlier interpretations by Malinowski et al. (2005) and Żelaźniewicz et al. (2009) is part of the EEC.

Despite apparent similarities, there are also significant differences between the Berthelsen's (1998) hypothesis and the interpretation presented in this paper. The results reported here exclude not only the idea of an early Palaeozoic strike-slip suture along the TTZ, but also that of an early Permian crustal-scale dip-slip fault zone, the throw on which would have to be large enough to change the thickness of the crust (Berthelsen 1998). This is illustrated, for example, by the central part of the TTZ (Fig. 4), where the pre-Permian sedimentary succession is unaffected neither by Variscan, Caledonian or older tectonics (Mazur et al. 2015, 2017). The deformation of the Phanerozoic platform sedimentary cover over the middle part of the TTZ is limited to the effects of salt tectonics and relatively minor normal faults (cf. Krzywiec 2012, Mazur et al. 2015). On the other hand, in the very same area there is a significant contrast between the geophysical characteristics of the two adjacent crustal domains separated along the TTZ, the difference clearly visible on the potential field maps, and for a long time considered the basis for defining the TTZ itself. The probable explanation for this situation is that the potential fields effects along the TTZ reflect a deeply rooted boundary of two separate, distinct blocks in the crystalline basement that were amalgamated before Phanerozoic times, probably during the accretion of Rodinia in the Precambrian (see e.g., Meert \& Torsvik 2003, Li et al. 2008).

An important argument for the presence of a Precambrian collisional suture along the TTZ is a crustal keel underneath this zone. The presence of a keel was already postulated as an alternative interpretation of the $\mathrm{P} 4$ seismic reflection profile from the POLONAISE'97 survey (Grad et al. 2003). The crustal keel was also identified in the seismic reflection profile of the BABEL experiment (profile A) under the Sorgenfrei-Tornquist Zone NW of Bornholm (BABEL Working Group 1991, 1993, Thybo et al. 1994) and in two TTZ'92 profiles located in the Baltic Sea (Makris \& Wang 1994). The results of the BABEL and TTZ'92 experiments explain the origin of the Sorgenfrei-Tornquist Zone as a result of sedimentary basins inversion within the Alpine foreland at the Cretaceous to Paleogene transition (BABEL Working Group 1993, Makris \& Wang 1994, Thybo 2000). The crustal keel in this interpretation is considered to represent a "subversion" zone that is the lower crustal equivalent of a shallow basement horst. However, such an interpretation does not apply to the Polish segment of the TTZ, because PolandSPAN ${ }^{\text {ti }}$ profiles record no effects of the Alpine inversion at the scale of the whole crust, and, in particular, no presence of an uplifted crystalline basement horst.

In an alternative interpretation, the crustal's keel origin can be attributed to magmatic underplating of the crust by igneous bodies emplaced in the course of continental rifting at the transition from the Carboniferous to Permian (Thybo 2000). This possibility cannot be definitely ruled out for the TTZ. However, the important weakness of this interpretation is that the TTZ was beyond the range of the main volcanic centres associated with late Palaeozoic rifting. Consequently, the crustal keel along the TTZ is interpreted in our paper as the relic of a collisional suture formed due to Precambrian terrane amalgamation, when two crustal blocks of different thicknesses were welded together. The Precambrian age of amalgamation is indicated by the virtually undisturbed lower Palaeozoic sediments overlying the crystalline basement along the TTZ in central Poland (Fig. 4).

The crustal keel cannot be modelled, however, in SE Poland, using gravity data because of the presence of high density bodies that mask its potential effect in the gravity profiles (Fig. 4). Nevertheless, the results of deep refraction sounding indicate a local depression of Moho underneath the TTZ in SE Poland relative to its depth in the adjacent areas (e.g., Janik et al. 2005, Grad et al. 2006, Sroda et al. 2006). These observations have recently been confirmed in the PL-5100 profile of the PolandSPAN ${ }^{\text {tux }}$ survey that was re-processed to the upper mantle depth (Malinowski 2016). 


\section{CONCLUSIONS}

The studies summarized in this paper document two important features of the TTZ: (1) an extension of the EEC crust beyond the TTZ and its continuation towards the SW in the deep substratum of the Palaeozoic Platform and (2) the presence of a crustal keel underneath the TTZ. Both of these features are not linked by a cause-and-effect relationship. The presented results do not show how far SW-ward the attenuated Baltica margin extends under the cover of younger sediments. However, the current knowledge about the deep basement of Poland (Żaba 1999, Grad et al. 2002, Grad et al. 2003, Wilde-Piórko et al. 2010) suggests that the Baltica margin may extend up to the Kraków-Lubliniec and Odra or Dolsk Faults (Fig. 5). In this paper, the crustal keel is interpreted as a remnant of Precambrian collisional suture from the time of Rodinia amalgamation. However, given the various earlier interpretations of its origin (BABEL Working Group 1991, 1993, Thybo et al. 1994, Thybo 2000), the hypothesis presented here requires further study and verification based on new seismic data. Finally, the value and importance of regional deep reflection profiles, such as the PolandSPAN ${ }^{\mathrm{rax}}$ survey and the POLCRUST-01 profile, should be emphasized since they revived the debate on the nature of the TTZ and supplied it with new valuable data and arguments.

Rostislav Melichar and Jerzy Żaba are thanked for their constructive comments that significantly improved our manuscript.

\section{REFERENCES}

Antonowicz L., Hooper R. \& Iwanowska E., 2003, Synklina lubelska jako efekt cienkonaskorkowych deformacji waryscyjskich. Przegląd Geologiczny, 51, 344-350.

BABEL Working Group, 1991. Deep seismic survey images the structure of the Tornquist Zone beneath the Southern Baltic Sea. Geophysical Research Letters, 18, 1091-1094.

BABEL Working Group, 1993. Deep seismic reflection/refraction interpretation of critical structure along BABEL profiles A and B in the southern Baltic Sea. Geophysical Journal International, 112, 325-343.

Banka D., Pharaoh T.C., Williamson J.P. \& TESZ Project Potential Field Core Group, 2002. Potential field imaging of Palaeozoic orogenic structure in northern and central Europe. Tectonophysics, 360, 23-45.
Barnes G. \& Barraud J., 2012. Imaging geologic surfaces by inverting gravity gradient data with depth horizons. Geophysics, 77, 1, G1-G11.

Berthelsen A., 1998. The Tornquist zone northwest of the Carpathians: an intraplate pseudosuture. GFF, 120, 223-230.

Brochwicz-Lewiński W., Pożaryski W. \& Tomczyk H., 1981. Wielkoskalowe ruchy przesuwcze wzdłuż SW brzegu platformy wschodnioeuropejskiej we wczesnym paleozoiku. Przeglad Geologiczny, 8, 340, 385-396.

Brochwicz-Lewiński W., Pożaryski W. \& Tomczyk H., 1984. Sinistral strike-slip movements in central Europe in the Paleozoic. [in:] Symposium on Geodynamics, Jabłonna, 13-15 April, 1981, Publications of the Institute of Geophysics, Polish Academy of Sciences, 160, A-13, Państwowe Wydawnictwo Naukowe, Warszawa - Łódź, 3-13.

Čermák V., Šafanda J. \& Guterch A., 1989. Deep temperature distribution along three profiles crossing the Teisseyre-Tornquist tectonic zone in Poland. Tectonophysics, 164, 2-4, 151-163.

Dadlez R., Grad M. \& Guterch A., 2005. Crustal structure below the Polish Basin: is it composed of proximal terranes derived from Baltica? Tectonophysics, 411, 1-4, 111-128.

Franke D., 1995. The Caledonian terranes along the south-western border of the East European Platform evidence, speculation and open questions. Studia Geophysica et Geodaetica, 39, 3, 241-256.

Franke W., Dallmeyer R.D. \& Weber K., 1995. Geodynamic evolution. [in:] Dallmeyer R.D., Franke W. \& Matte P. (eds.), Pre-Permian Geology of Central and Eastern Europe, Springer-Verlag, Berlin, 579-593.

Grad M., Guterch A. \& Mazur S., 2002. Seismic refraction evidence for crustal structure in the central part of the Trans-European Suture Zone in Poland. [in:] Winchester J.A., Pharaoh T.C. \& Verniers J. (eds.), Palaeozoic Amalgamation of Central Europe, Geological Society Special Publication, 201, Geological Society, London, 295-309.

Grad M., Jensen S.L., Keller G.R., Guterch A., Thybo H., Janik T., Tiira T., Yliniemi J., Luosto U., Motuza G., Nasedkin V., Czuba W., Gaczyński E., Środa P., Miller K.C., Wilde-Piórko M., Komminaho K., Jacyna J. \& Korabliova L., 2003. Crustal structure of the Trans-European suture zone region along POLONAISE '97 seismic profile P4. Journal of Geophysical Research, Solid Earth, 108, B11. DOI: 10.1029/2003JB002426.

Grad M., Guterch A., Keller G.R., Janik T., Hegedűs E., Vozár J., Ślączka A., Tiira T. \& Yliniemi J., 2006. Lithospheric structure beneath trans-Carpathian transect from Precambrian platform to Pannonian basin: CELEBRATION 2000 seismic profile CEL05. Journal of Geophysical Research, Solid Earth, 111, B3. DOI: 10.1029/2005JB003647.

Grad M. \& Polkowski M., 2016. Seismic basement in Poland. International Journal of Earth Sciences, 105, 1199-1214.

Guterch A. \& Grad M. 2006. Lithospheric structure of the TESZ in Poland based on modern seismic experiments. Geological Quarterly, 50, 23-32.

Guterch A., Wybraniec S., Grad M., Chadwick R., Krawczyk C., Ziegler P., De Vos W. \& Thybo H., 2010. Crustal structure and structural framework. [in:] Doornenbal J. \& Stevenson A. (eds.), Petroleum Geological Atlas of the Southern Permian Basin Area, Houten, EAGE Publications, 11-23. 
Janik T., Grad M., Guterch A., Dadlez R., Yliniemi J., Tiira T., Keller G.R., Gaczyński E. \& Celebration 2000 Working Group, 2005. Lithospheric structure of the Trans-European Suture Zone along the TTZ-CEL03 seismic transect (from NW to SE Poland). Tectonophysics, 411, 1-4, 129-156.

Janik T., Grad M. \& Guterch A., 2009. Seismic structure of the lithosphere between the East European Craton and the Carpathians from the net of CELEBRATION 2000 profiles in SE Poland. Geological Quarterly, 53, 1, 141-158.

Królikowski C. \& Petecki Z., 1995. Atlas grawimetryczny Polski $=$ Gravimetric Atlas of Poland. Państwowy Instytut Geologiczny, Warszawa.

Królikowski C. \& Wybraniec S., 1996. Gravity and magnetic maps of Poland - historical background and modern presentation. [in:] The Hundredth Anniversary of the First Chair of Geophysics. In Memory of Maurycy Pius Rudzki, Professor of the Jagiellonian University, Publications of the Institute of Geophysics, Polish Academy of Sciences, 273, M18, Państwowe Wydawnictwo Naukowe, Warszawa - Łódź, 87-92.

Krzywiec P., 2012. Mesozoic and Cenozoic evolution of salt structures within the Polish basin: An overview. [in:] Alsop G.I., Archer S.G., Hartley A.J., Grant N.T. \& Hodgkinson R. (eds.), Salt Tectonics, Sediments and Prospectivity, Geological Society Special Publication, 363, Gelogical Society, London, 381-394.

Krzywiec P., Malinowski M., Mazur S., Buffenmyer V. \& Lewandowski M. 2014. Structure and Phanerozoic evolution of the SW edge of the East European Craton in Poland - new insight from high-effort seismic reflection data (project PolandSPAN). Geologia Sudetica, 42, $46-48$

Krzywiec P., Mazur S., Gągała Ł., Kufrasa M., Lewandowski M., Malinowski M. \& Buffenmyer, V., 2017a. Late Carboniferous thin-skinned compressional deformation above the SW edge of the East European craton as revealed by seismic reflection and potential field data - Correlations with the Variscides and the Appalachians. [in:] Law R.D., Thigpen J.R., Merschat A.J. \& Stowell H.H. (eds.), Linkages and Feedbacks in Orogenic Systems, Geological Society of America Memoir, 213, Geological Society of America, 353-372.

Krzywiec P., Gągała Ł., Mazur S., Słonka Ł., Kufrasa M., Malinowski M., Pietsch K. \& Golonka J., 2017b. Variscan deformation along the Teisseyre-Tornquist Zone in SE Poland: Thick-skinned structural inheritance or thinskinned thrusting? Tectonophysics, 718, 30, 83-91.

Li Z.X., Bogdanova S.V., Collins A.S., Davidson A., De Waele B., Ernst R.E., Fitzsimons I.C.W., Fuck R.A., Gladkochub D.P., Jacobs J. \& Karlstrom K.E., 2008. Assembly, configuration, and break-up history of Rodinia: a synthesis. Precambrian Research, 160, 1, 179-210.

Majdański M., 2012. The structure of the crust in TESZ area by kriging interpolation. Acta Geophysica, 60, 59-75.

Majorowicz J.A., Čermak V., Šafanda J., Krzywiec P., Wróblewska M., Guterch A. \& Grad M., 2003. Heat flow models across the Trans-European Suture Zone in the area of the POLONAISE'97 seismic experiment. Physics and Chemistry of the Earth, Parts A, B and C, 28, 9, 375-391.
Malinowski M., 2016. Deep reflection seismic imaging in SE Poland using extended correlation method applied to PolandSPAN ${ }^{\mathrm{m}}$ data. Tectonophysics, 689, 107-114.

Malinowski M., Żelaźniewicz A., Grad M., Guterch A., Janik T. \& Celebration Working Group, 2005. Seismic and geological structure of the crust in the transition from Baltica to Palaeozoic Europe in SE Poland - CELEBRATION 2000 experiment, profile CEL02. Tectonophysics, 401, 1, 55-77.

Malinowski M., Guterch A., Narkiewicz M., Probulski J., Maksym A., Majdański M., Środa P., Czuba W., Gaczyński E., Grad M., Janik T., Jankowski L. \& Adamczyk A., 2013. Deep seismic reflection profile in Central Europe reveals complex pattern of Paleozoic and Alpine accretion at the East European Craton margin. Geophysical Research Letters, 40, 15, 3841-3846.

Malinowski M., Guterch A., Narkiewicz M., Petecki Z., Janik T., Sroda P., Maksym A., Probulski J., Grad M., Czuba W., Gaczynski E., Majdanski M. \& Jankowski L., 2015. Geophysical constraints on the crustal structure of the East European Platform margin and its foreland based on the POLCRUST-01 deep reflection seismic profile. Tectonophysics, 653, 109-126.

Makris J. \& Wang S.R., 1994. Crustal structure at the Tornquist-Teisseyre zone in the Southern Baltic Sea. Zeitschrift für Geologische Wissenschaften, 22, 47-54.

Mazur S., Mikolajczak M., Krzywiec P., Malinowski M., Buffenmyer V. \& Lewandowski M., 2015. Is the Teisseyre-Tornquist Zone an ancient plate boundary of Baltica? Tectonics, 34, 12, 2465-2477.

Mazur S., Mikołajczak M., Krzywiec P., Malinowski M., Buffenmyer V. \& Lewandowski M., 2016a. Reply to Comment by M. Narkiewicz and Z. Petecki on "Is the Teisseyre-Tornquist Zone an ancient plate boundary of Baltica?". Tectonics, 35, 6, 1600-1607.

Mazur S., Mikołajczak M., Krzywiec P., Malinowski M., Lewandowski M. \& Buffenmyer V., 2016b. Pomeranian Caledonides, NW Poland - A collisional suture or thinskinned fold-and-thrust belt? Tectonophysics, 692, 29-43.

Mazur S., Krzywiec P., Malinowski M., Lewandowski M., Aleksandrowski, P. \& Mikołajczak M., 2017. Tektoniczne znaczenie strefy Teisseyre'a-Tornquista w świetle nowych badań. Przegląd Geologiczny, 65, 12, 1511-1520.

Meert J.G. \& Torsvik T.H., 2003. The making and unmaking of a supercontinent: Rodinia revisited. Tectonophysics, 375, 1, 261-288.

Mikołajczak M., 2016. Analiza struktury podłoża prowincji łupków gazonośnych centralnej Polski w oparciu o dane grawimetryczne i magnetyczne. Instytut Nauk Geologicznych Polskiej Akademii Nauk, Kraków [Ph.D. thesis].

Narkiewicz M., Maksym A., Malinowski M., Grad M., Guterch A., Petecki Z., Probulski J., Janik T., Majdański M., Środa P., Czuba W., Gaczyński E. \& Jankowski L., 2015. Transcurrent nature of the Teisseyre-Tornquist Zone in Central Europe: results of the POLCRUST-01 deep reflection seismic profile. International Journal of Earth Sciences, 104, 3, 775-796.

Nawrocki J. \& Poprawa P., 2006. Development of trans-European Suture Zone in Poland: from Ediacaran rifting to early Palaeozoic accretion. Geological Quarterly, 50, 1, 59-76. 
Perchuć E., 1984. Structure of the Earth's crust in Southestern Poland. [in:] Symposium on Geodynamics. Jabłonna, 13-15 April 1981, Publications of the Institute of Geophysics, Polish Academy of Sciences, 160, A-13, Państwowe Wydawnictwo Naukowe, Warszawa-Łódź, 77-86.

Pharaoh T.C., 1999. Palaeozoic terranes and their lithospheric boundaries within the Trans-European Suture Zone (TESZ): a review. Tectonophysics, 314, 17-41.

Poprawa P., Paszkowski M., Fanning M.C., Pécskay Z., Nawrocki J. \& Sikorska M., 2006. Charakterystyka geochronologiczna obszarów źródłowych dla dolnopaleozoicznych utworów z NW kratonu wschodnioeuropejskiego oraz strefy Koszalin-Chojnice; datowania detrytycznych łyszczyków (K/AR) i cyrkonów (U/PB SHRIMP). [in:] Matyja H. \& Poprawa P. (red.), Ewolucja facjalna, tektoniczna i termiczna pomorskiego segmentu szwu transeuropejskiego oraz obszarów przyległych, Prace Państwowego Instytutu Geologicznego, 186, Państwowy Instytut Geologiczny, Warszawa, 149-164.

Pożaryski W., Brochwicz-Lewiński W. \& Tomczyk H., 1982. O heterochroniczności linii Teisseyre'a-Tornquista. Przeglad Geologiczny, 11, 355, 569-574.

Pożaryski W., 1990. Kaledonidy środkowej Europy - orogenem przesuwczym złożonym z terranów. Przeglą Geologiczny, 38, 1, 1-9.

Środa P., Czuba W., Grad M., Guterch A., Tokarski A.K., Janik T., Rauch M., Keller G.R., Hegedüs E. \& Vozár J., 2006. Crustal and upper mantle structure of the Western Carpathians from CELEBRATION 2000 profiles CEL01 and CEL04: seismic models and geological implications. Geophysical Journal International, 167, 2, 737-760.

Talwani M. \& Ewing M., 1960. Rapid computation of gravitational attraction of three-dimensional bodies of arbitrary shape. Geophysics, 25, 203-225.

Teisseyre W., 1921. O stosunku wewnętrznych brzegów zapadlin przedkarpackich do krawędzi fliszu karpackiego. Sprawozdania Polskiego Instytutu Geologicznego, I $(2,3), 103-138$.

Thybo H., Abramovitz T., Lassen A. \& Schjøth F., 1994. Deep structure of the Sorgenfrei-Tornquist zone interpreted from BABEL seismic data. Zeitschrift für Geologische Wissenschaften, 22, 3-17.

Thybo H., 2000. Crustal structure and tectonic evolution of the Tornquist Fan region as revealed by geophysical methods. Bulletin of the Geological Society of Denmark, $46,145-160$.
Tornquist A., 1908. Die Feststellung des Sudwesttrendes des baltich-russisschen Schiedes und die geotektonische $\mathrm{Zu}$ gehorigheit der ost-preussischen Scholle. Schriften der Physikalisch-Oekonomischen Gesellschaft zu Königsberg, $49,1,1-12$.

Torsvik T.H., Olesen O., Ryan P.D. \& Trench A., 1990. On the palaeogeography of Baltica during the Palaeozoic: new palaeomagnetic data from the Scandinavian Caledonides. Geophysical Journal International, 103, 1, 261-279.

Torsvik T.H., Smethurst M.A., Van Der Voo R., Trench A., Abrahamsen N. \& Halvorsen E., 1992. Baltica. A synopsis of Vendian-Permian palaeomagnetic data and their palaeotectonic implications. Earth-Science Reviews, 33, 2, 133-152.

Wernicke B., 1985. Uniform-sense normal simple shear of the continental lithosphere. Canadian Journal of Earth Sciences, 22, 1, 108-125.

Wilde-Piórko M., Świeczak M., Grad M. \& Majdański M., 2010. Integrated seismic model of the crust and upper mantle of the Trans-European Suture zone between the Precambrian craton and Phanerozoic terranes in Central Europe. Tectonophysics, 481, 1, 108-115.

Winchester J.A. \& The Pace TMR Network Team, 2002. Palaeozoic amalgamation of Central Europe: new results from recent geological and geophysical investigations. Tectonophysics, 360, 1-4, 5-21.

Wybraniec S., 1999. Transformations and visualization of potential field data. Polish Geological Institute Special Papers, 1, Polish Geological Institute, Warszawa, 1-59.

Zhu H. \& Tromp J., 2013. Mapping tectonic deformation in the crust and upper mantle beneath Europe and the North Atlantic Ocean. Science, 341, 6148, 871-875.

Zhu H., Bozdağ E. \& Tromp J., 2015. Seismic structure of the European upper mantle based on adjoint tomography. Geophysical Journal International, 201, 1, 18-52.

Żaba J., 1999. Ewolucja strukturalna utworów dolnopaleozoicznych w strefie granicznej bloków górnośląskiego i małopolskiego. Prace Państwowego Instytutu Geologicznego, 166, PIG, Warszawa.

Żelaźniewicz A., Buła Z., Fanning M., Seghedi A. \& Żaba J., 2009. More evidence on Neoproterozoic terranes in Southern Poland and southeastern Romania. Geological Quarterly, 53, 1, 93-124. 